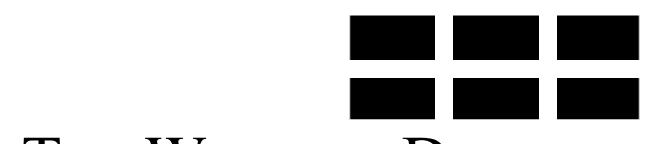

THE WILLIAM DAVIDSON INSTITUTE AT THE UNIVERSITY OF MICHIGAN BUSINESS SCHOOL

\title{
WAGE DETERMINATION: PRIVATISED, NEW PRIVATE AND STATE OWNED COMPANIES. EMPIRICAL EVIDENCE FROM PANEL DATA
}

\author{
By: Tomasz Mickiewicz and Kate Bishop
}

William Davidson Institute Working Paper Number 584

June 2003 


\title{
Wage Determination: Privatised, New Private and State OWNED COMPANIES. EMPIRICAL EVIDENCE FROM PANEL DATA*
}

\author{
Tomasz Mickiewicz $\$$ and Kate Bishop $\dagger$
}

$\ddagger$ SSEES at University College London. Senate House, Malet Street, London WC1E 7HU

T.Mickiewicz@ssees.ac.uk. Corresponding author

$\uparrow$ SSEES at University College London. Senate House, Malet Street, London WC1E 7HU

K.Bishop@ssees.ac.uk

Copyright ownership T.Mickiewicz and K.Bishop

\begin{abstract}
This paper examines the determinants of wage pressure in large companies, including ownership characteristics and the impact of regional labour markets. By using a panel of 329 Polish largest firms during the period 1997- 2001, we find evidence of rent sharing activities, however there is also asymmetry in quasi rent elasticity of wages. The wage setting mechanism seems to differ between new private companies, privatised companies, state firms and mixed ownership. In particular, wages in state firms are highly responsive to regional labour market conditions, while firms in other sectors are not. Rent sharing is visible in both the state sector and new private companies, yet several specific characteristics differ. On the other hand, quasi rent elasticity appears to be suppressed in privatised companies.
\end{abstract}

Keywords: wages, quasi-rents, de novo firms, privatisation, unemployment

JEL Classification: C23, D21, J21, L33, P31

\footnotetext{
* This research was financed the European Commission Framework 5 Project, "Regional Labour Market Adjustment in the Accession Candidate Countries" (ACCESSLAB). The authors would like to express gratitude to Maciej Baltowski, Beata Manthey, Zbigniew Pastuszak and Anna Zalewska for their involvement in joint effort of developing the dataset. We thank Peter Huber and Gabor Körösi for providing useful comments on earlier draft. We also benefited from discussing the paper at seminars in Budapest University and in Trinity College, Dublin. Nonetheless, we take responsibility for all remaining errors.
} 


\section{WAGES, INSIDERS AND OWNERSHIP OF ENTERPRISES}

Transition economies provide a useful ground for testing hypotheses related to ownership of industrial enterprises. As argued by Demsetz and Lehn (1985) and again more recently - by Demsetz and Villalonga (2001), long established markets for corporate control produce equilibria, where sector-specific efficient types of companies survive and inefficient ones disappear. In contrast, transition economies offer a plethora of ownership and organisational forms, created after the removal of command economy system. In this paper, we wish to investigate the implications of corporate control for wage setting patterns.

When the command economy ${ }^{1}$ system collapsed, both institutional reforms and stabilisation policies resulted in the initial 'transitional recession': plummeting labour demand, rising unemployment and a temporary decrease in real wages (see Huber et al. 2002, Mickiewicz and Bell 2000, Boeri et al. 1998). As Huber et al. (2002) state, the initial drop in employment levels and surge in unemployment was expected at the onset of the transition process. This was part of the 'transformational recession' (Kornai, 1995; Blanchard 1997). However, even when the output growth had recovered, employment levels did not. Employment levels in 1996 were between 5.6 (Romania) and 22-23 (Bulgaria, Hungary) percentage points below pre transition levels (Mickiewicz and Bell 2000; Boeri et al. 1998). Unemployment levels also appear to be heterogeneous among transition economies. Huber et al.. (2002) report that while the average unemployment rates in some of these countries are in the lowest EU range (Hungary, Slovenia), some others exceed significantly the maximum rate observed in the EU (notably Bulgaria and Poland).

Poland, the second largest transition economy, is an interesting case, as the macroeconomic trade-off between wage pressure and unemployment seems to be particularly unfavourable. Between 1998-2001, it underwent an increase in unemployment rate from below $10 \%$ to $16 \%$, in order to reduce real wage growth from an unsustainable $8 \%$ in real terms to $4 \%$.

\footnotetext{
${ }^{1}$ See Jackman and Rutkowski (1994) or Boeri at al. (1998) for a description of labour markets under the command economy.
} 
The motivation of this paper is to look at some microeconomic foundations of this phenomenon. In fact, research on the impact of privatisation on labour market outcomes and firm level wage pressure in transition economies is limited. ${ }^{2}$

Our aim is to research the determinants of wage growth at the firm level during the period of 1997-2001 in Poland. In particular, we look at the effects of the privatisation process on wage setting. We wish to explore if the wage determination mechanism is different for state owned, privatised and 'de novo' private companies.

A key research question relates to the link between quasi rents and wage increases. The bargaining and rent sharing model imply the link between the company's ability to pay wages, provided that the bargaining position of employees is sufficiently strong. However, also, the temporary frictions may result in an upward sloping supply curve of labour (Hildreth and Oswald 1997). Therefore, 'a positive demand shock may trace out a simultaneous rise in total firm profits and in wages' (Ibid. p. 321). Only in the long run, is the increase eradicated by an increase in workers entering the labour market, which then eliminates the wage premium. Thus, in the short run, the correlation between wage and financial performance may be explained by both the competitive model and bargaining / rent sharing model. Only estimation of the long run provides an empirical test to distinguish between the two models, as according to the competitive model the correlation is expected to disappear.

Given this argument, the link between ability to pay and wage increases amongst different ownership categories becomes an important testing ground, where estimation of the long run effects is difficult. Moreover, different ownership categories may be characterised by different bargaining structures, while operating on the same markets. This argument can naturally be tested in the environment of transition economies. ${ }^{3}$ Several results are available. First, Dong (1998) and Lee (1999) examine China. Dong (1998) finds direct evidence that in the township -village enterprises, wage changes are responsive to financial conditions. Similarly, Lee (1999) finds that profit per

\footnotetext{
${ }^{2}$ For an overview of earlier results see Svejnar 1999.

${ }^{3}$ Haskel and Szymanski (1993) test the impact of privatisation on wage setting in the UK. However, their results are not directly applicable to the transition economies for two reasons: /1/ legal and actual control rights in the UK companies before privatisation were very different from pre-privatisation state-owned enterprises in transition economies; $/ 2 /$ their model is focused on utilities and network industries, where privatisation is parallel to change in regulatory regime; in contrast most of privatisations in transition countries were in core manufacturing branches.
} 
worker and change in profit per worker is positively associated with changes in wages for several types of employee.

Other researchers have also examined the impact of productivity on wage determination in European transition economies, taking into account differences in wage setting across ownership and organisational characteristics. ${ }^{4}$

An interesting feature of this research is that while differences between ownership sectors had been hardly detectable at the beginning of transition period, they became more evident later. As both the privatisation process and secondary transfers of ownership continue, the economic system evolves towards more stable structures, and this includes a bargaining and wage setting framework.

In particular, Basu et al. (2000) find that ownership and legal status of firms do not have a systematic effect on employment and wages for the early transition period, i.e. 1988-1992 in Poland, Czech Republic and Slovakia. In contrast, Grosfeld and Nivet (1999) - using a sample of large Polish manufacturing firms (taken from the same dataset we use, but in an earlier period) - find that a change in revenue per employee leads to changes in wages over the period of 1990-94; moreover there are significant differences between ownership sectors. Also Christev and Fitzroy (2002) employ a survey based panel of large Polish firms, in order to study wage and employment adjustment comparing a range of ownership and organisational forms. Their dataset covers 1994-1997, an even later period than Grosfeld and Nivet (1999), which may better capture some of the changes due to privatisation. Both studies confirm rent sharing behaviour in firms, where the position of insiders is strong.

Our approach stems from this tradition. Yet, while we agree that the position of insiders may be crucial for wage determination outcomes, we also believe that there is still an interesting gap in empirical literature in tackling this issue. Namely, we argue that an interesting distinction - which to our best knowledge has been so far overlooked in literature on wage setting in a transition environment - relates to the contrast between new private firms on one hand and both state and privatised firms on the other.

\footnotetext{
${ }^{4}$ Here, we focus primarily on research based on enterprise level data. Slightly different questions are typically asked by researchers, who focus either on individual data or on regional level data. For results and discussion, see in particular Brainerd (2002), Lehmann and Wadsworth (2000), Adamchik and Bedi (2000), Lehmann and Wadsworth (2000), Boeri at al., 1998; Pohl et al., 1997.
} 
The corresponding question relates to the magnitude of the structural break in companies' behaviour induced by privatisation. A possible argument is that a mere change in ownership does not result automatically in a change in the way the company operates, due to organisational inertia. Correspondingly, new companies may start with a more efficient mode of operation, without a prolonged process of adjustment. In general, it is not ownership per se, but organisational features of the company, which may affect performance. According to this line of argument, the privatisation process may change little, in particular the position of insiders may be left unchanged. ${ }^{5}$ From this perspective, transition economies offer unique opportunities for comparisons. During the post-communist transition, an important role has been played by new market entries, that is companies, which were neither privatised nor state owned but so called 'de novo' firms, i.e. new companies launched after the transition process had started. This sector, sometimes branded as 'entrepreneurial', accounts for a high proportion of output, including a significant number of large companies (for early size estimates of this sector for transition economies, see Johnson et al. 1997). The quick emergence of the 'entrepreneurial sector' may be less of a paradox than it looks at first sight. First, some of those companies are green-field investment by foreign investors. Second, both domestic and foreign entrepreneurs could take advantage of the initial gaps in the structure of production, which correspond to high consumer demand, high growth opportunities, and high opportunities to sustain development from retained earnings. And last but not least, in Poland, the growth of those companies could be strongly enhanced by the transfer of assets from the state sector, taking advantage from both privatisation opportunities and direct asset sales by the state sector firms (see Balcerowicz, 1995). The process illustrates the point made earlier: the factors which account for the performance outcomes, may relate neither to characteristics of both assets nor labour, as those were poached from the state firms. An important point however is that the new entrepreneurs may be able to impose new organisational forms easily, which could possibly contrast with the inertia of privatised companies ${ }^{6}$.

\footnotetext{
${ }^{5}$ One possible theoretical perspective that can be applied to account for that relates to new institutional economics. See Furubotn 2001.

${ }^{6}$ For example Jones (1998) finds that insider ownership is linked to organisation inertia in the Russian case.
} 
From recent studies on other aspects of performance in transition countries (Carlin et al. 1999; Carlin et al. 2001; and overview in Havrylyshyn and McGettingan, 1999), we know that the distinction between old firms and new firms appears to be significant.

Focusing on that distinction, our study used four ownership categories (i.e. state companies, state companies with minority private ownership, privatised companies and companies established as private - de novo). Relatively large ownership groups enable us to check for corresponding interactive effects with more confidence, in order to see if the wage pressure response to ability to pay differs.

Revenue per employee is used as a proxy for ability to pay by other researchers, including Nickell and Wadhwani (1990), Grosfeld and Nivet (1999), Basu et al. (2000), Christev and Fitzroy (2002), It is typically interpreted as a corresponding measure to labour productivity. Yet, this interpretation is questionable for two reasons. First, the level of sales per employee depends heavily on capital intensity of production. Second, by construction, changes in sales-labour ratio reflect both increase in sales and changes in employment. Thus, the indicator is difficult to interpret in terms of productivity. However, instead of rejecting this approach, we propose to add a qualification. Namely, we accept the line of reasoning presented by Van Reenen (1996), who argues that the difference between revenue per head and industrial wages is a good indicator of quasi rent. Thus if revenue per head is used, it is important either to include industrial wage in the chosen specification orto impose a linear restriction and focus directly on the difference between the two indicators. Alternatively, some studies use profits per employee as a proxy for quasi rent (Fakhfakh and Fitzroy 2002, Hildreth and Oswald 1997). Yet, there are two problems. First, this measure excludes depreciation, which should be included in available cash flow. Second, by construction profits are negatively correlated with wages. ${ }^{7}$ The problem could be alleviated by use of instruments, but the approach brings in different estimation problems - as always, good instruments are difficult to find. ${ }^{8}$ The key results of our research show that wage determination in Poland differs far more for the new-old cross-section, than for state-private cross-section. In addition,

\footnotetext{
${ }^{7}$ See Van Reenen (1996). Due to restricted data availability, researchers on transition economies, used some other proxies for the firm' performance. See Djankov and Murell, 2002 for overview.
} 
the link with employment is important and the outside factors such as the sectoral wages, regional unemployment and employment rate are important in wage determination. We will now turn to discuss the latter issue.

\section{LABOUR MARKET CONDITIONS AND WAGE PRESSURE}

Last but not least, outside labour market conditions play an important role in wage determination. The factors, which appear often in the estimation of wage equations, are regional unemployment and outside wages. The negative relationship between regional unemployment rates and wages corresponds to the wage curve. In addition, one should expect that the impact of short term unemployment is stronger (Nickell and Wadhwani 1990). This is due to the fact that the long - term unemployed are supposed to be inefficient in their job search and therefore they do not have an impact on wage determination. A counter argument might be that the large percentage of long-term unemployed represents a depressed labour market, which could have a cooling effect on wages.

The empirical results confirming microeconomic wage curve are common in studies of European transition economies, as in Grosfeld and Nivet (1999), Duffy and Walsh (2001), Christev and FitxRoy (2002) - which all focus on Poland, Christofides and Oswald (1992) for developed economies such as the UK, and Dong (1998) for China. They build on earlier studies related to OECD countries. In particular, Blanchflower (1990) found that four alternative measures of unemployment are negatively and significantly related to annual earnings. Holmund and Zetterberg (1991) also hypothesise that unemployment (they use an economy wide unemployment rate) is likely to depress wages, ${ }^{9}$ in their study of the determinants of industry wages in five countries. Their results show that the effects of aggregate unemployment vary across countries: negative as expected for Sweden, Finland and Germany, yet positive for Norway and the USA. The result is interesting as it possibly reflects differences in institutional labour market characteristics implying that wage curve may be labour

${ }^{8}$ One possibility is to use sectoral level data on profits and demand shocks. This is the approach taken by Abowd and Lemieux (1993) and Christofides and Oswald (1992). Given we wish to control for sectoral wages, this path proved to be difficult to follow, due to multicollinearity problems. 
market institution specific. In particular, the positive coefficient for the USA may imply a more competitive labour market which can be interpreted along the lines of the 'first generation' models (see below). Earlier identified cross-country differences and evolving institutional frameworks in transition countries, make testing wage curves for transitional economies a non-trivial task.

\footnotetext{
${ }^{9}$ However, they note that the depressing effect of higher unemployment is likely to be bigger in an aggregate wage equation.
} 
William Davidson Institute Working Paper 584

Table 1 . Results by other authors

\begin{tabular}{|c|c|c|c|}
\hline Author & Coefficier & t for: & Timespan and methods \\
\hline & \begin{tabular}{|l} 
Unemploy \\
ment
\end{tabular} & $\begin{array}{l}\text { Performan } \\
\text { ce }\end{array}$ & \\
\hline $\begin{array}{l}\text { Christev and Fitzroy (2002) } \\
\text { Poland }\end{array}$ & $-0.06^{10}$ & $0.54^{11}$ & $\frac{1994-1997}{\text { GMM }}$ \\
\hline $\begin{array}{l}\text { Duffy and Walsh (2001) } \\
\text { Poland }\end{array}$ & $\underline{-0.15}$ & $\underline{\mathrm{NA}}$ & $\frac{1991-1996}{2 \text { SLS }}$ \\
\hline $\begin{array}{l}\text { Blanchflower (2001) } \\
\text { Eastern Europe }\end{array}$ & $\begin{array}{l}\underline{\text { Poland }=-} \\
\underline{0.13} \\
\underline{\text { Rus }}=- \\
\underline{0.07} \\
\underline{\text { Slovenia }=} \\
\underline{-0.05} \\
\underline{\text { Hungary }=} \\
\underline{-0.05}\end{array}$ & $\underline{\mathrm{NA}}$ & $\begin{array}{l}\text { 1990-1997 } \\
\text { Fixed effects } \\
\end{array}$ \\
\hline $\begin{array}{l}\text { Grosfeld and Nivet (1999) } \\
\text { Poland }\end{array}$ & $\underline{-0.03}$ & $\underline{0.14}$ & $\frac{1991-1997}{\text { Fixed effects }}$ \\
\hline $\begin{array}{l}\text { Montuengaat al. (2003) } \\
\text { Europe }\end{array}$ & $\begin{array}{l}\underline{\text { France }=-} \\
\underline{0.16} \\
\underline{\text { Italy }}=- \\
\underline{0.08} \\
\text { Portugal }= \\
\underline{-0.01} \\
\underline{\text { Spain }=-} \\
\underline{0.24} \\
\underline{\text { UK }=-0.2}\end{array}$ & $\underline{\mathrm{NA}}$ & $\begin{array}{l}\text { 1994-1996 } \\
\underline{\text { GLS }}\end{array}$ \\
\hline $\begin{array}{l}\text { Goux and Marin (1999) } \\
\text { France }\end{array}$ & $\underline{\mathrm{NA}}$ & $\underline{0.05}$ & $\begin{array}{l}\text { 1990-1995 } \\
\text { Fixed effects } \\
\end{array}$ \\
\hline Hildreth and Oswald (1997) UK & $\underline{\mathrm{NA}}$ & $\underline{1.13}$ & $\frac{1980-86}{\text { GMM }}$ \\
\hline $\begin{array}{l}\text { Christofides and Oswald (1992) } \\
\text { Canada }\end{array}$ & $\underline{-0.08}$ & $\underline{0.003}$ & $\underline{\text { GLS }}$ \\
\hline Gregg and Machin (1992) UK & $\underline{\mathrm{NA}}$ & $\underline{0.12}$ & $\frac{1983-84}{\text { GMM }}$ \\
\hline $\begin{array}{l}\text { Holmund and Zetterberg (1991) } \\
\text { US }\end{array}$ & $\underline{0.02}$ & $\underline{0.09}$ & $\frac{1965-85}{\text { Autoregressive model }}$ \\
\hline Blanchlower (1990) & $\underline{-0.1}$ & $\underline{\mathrm{NA}}$ & $\begin{array}{l}\text { 1983-6,89 } \\
\text { Pooled techniques }\end{array}$ \\
\hline $\begin{array}{l}\text { Nickell and Wadhwani (1989) } \\
\text { UK }\end{array}$ & $\underline{-0.01}$ & $\underline{\mathrm{NA}}$ & $\frac{1975-1982}{\text { GMM }}$ \\
\hline
\end{tabular}

One should note however that the link between wages and unemployment can be interpreted not only in terms of bargaining theory but also in terms of efficiency wage theory, where wages do not result from bargaining process but from optimising decisions by the firms (Shapiro and Stiglitz, 1984).

\footnotetext{
${ }^{10}$ Christev and Fitzroy (2002), Christofides and Oswald (1992), Grosfeld and Nivet (1999), Montuenga (2003), Duffy and Walsh (2001) and Blanchflower (2001) use regional rates, Nickell and Wadwhani (1989) use imdustry rates and Holmund and Zetterberg use aggregate rate.

${ }^{11}$ Christev and Fitzroy (2002) and Grosfeld and Nivet (1999) both use growth in productivity, Hildreth and Oswald (1997) and Christofides and Oswald (1992) use profit per employee, Gregg and Machin (1992) uses sales per employee, Holmund and Zetterberg (1991) uses value added and Goux and Maurin (1989) uses operating income per empolyee.
} 
In addition, there is a dissenting tradition of the neo-classical or "first generation" of papers by researchers such as Harris- Todaro (1970), Hall (1970) and Rosen (1986) predicting that unemployment and wages would move in the same direction. This relies on the perfectly competitive theory and compensating differentials. Cahuc et al. (2002) summarise this idea: "the higher the risk of losing one's job, the higher the wage to compensate for this risk," (p15). Also wages may have to compensate for job characteristics, location, flexibility, risk to health etc.

Rosen (1986) provides some evidence of the theory of equalising differences, which "refers to the observed wage differentials required to equalise total monetary and non monetary advantages or disadvantages among worker activities and among workers themselves". The actual wage paid is the sum of labour services and worker characteristics, plus job attributes. Thus jobs offering unfavourable conditions pay wage premiums as offsetting compensation to attract workers. Unfavourable conditions include risk to health ${ }^{12}$, inflexible hours or the possible risk of lay off and unemployment, the latter being relevant to the private sector companies.

Duffy and Walsh (2001) provide a brief survey of the "first generation of papers" written in the 1970's and 1980's, which all found a positive relationship between wages and unemployment. However, they criticise this line of research for failing to control for regional fixed effects. They argue that after including regional dummies, the relationship between regional pay and unemployment are in fact negatively correlated (Ibid., p.25).

Nevertheless, the evidence is still not conclusive. A recent study by Cahuc et al. (2002) on a panel of French firms finds some new evidence that confirms the predictions of equalising differences, as unions accept lower aggregate wages when workers benefit from lower unemployment risk. Thus the higher the risk of loosing a job, the higher the wage needs to be to compensate for risk, i.e. the wage bargaining mechanism leads to equalising differences between firms (Ibid., p15). As argued above, the parameters of the wage curve are conditional on labour market institutions (competitiveness in particular), and therefore neither cross country nor time invariant, and still worth further testing.

\footnotetext{
${ }^{12}$ One example Rosen (1986) gives is that in the Soviet era large wage premia were paid to workers in the permafrost regions of Siberia.
} 
A recent concise theoretical model underpinning the wage curve is offered by Sato (2000). His benchmark case is relevant to transition economies, as it describes the case where workers are not mobile ${ }^{13}$. The explanation for the wage curve is given by a search model with regional variations in productivity. By adopting wage bargaining assumptions the region with higher productivity experiences higher wages and lower unemployment. Even, if workers are mobile, the traditional wage curve may hold if the search model is combined with regional variations in productivity and a city structure with congestion costs. While all the workers will want to live and work in the central business district, the living area of workers spreads and commuting and rental costs escalate. These costs will deter concentration in one region even if there are differences in productivity among regions.

Where we intend to contribute to this discussion, is to point out that unemployment elasticity of wages is ownership specific. As a result, in the environment where different types of firms respond differently to labour market conditions, the parameters of the wage curve may evolve along the ownership transformation.

\section{Hypotheses}

Here, we summarise our main hypotheses to be tested in the empirical section.

First, we expect that the link between quasi rents and wages to be ownership/ organisational sector specific. In particular, as discussed above, we wish to check if the contrast between new and old companies dominates the comparison between the state and privatised sector.

Second, due to labour market characteristics of the transition counties and Poland in particular, we expect to find confirmation for the microeconomic wage curve.

However, we intend to explore if the results are invariant along the ownership cross section.

Third, we wish to test for asymmetry ${ }^{14}$ effects in quasi rent elasticity of wages, to see if the pattern evolves over time, comparing with earlier results, Grosfeld and Nivet (1999) in particular.

\footnotetext{
${ }^{13}$ Low spacial mobility in transition countries is discussed in Huber et al. (2002).

${ }^{14}$ The asymmetry hypothesis was suggested by Lindbeck and Snower (1987). They propose that the downward responsiveness of wages to a demand shock is less than that of the wage response to a positive demand shock.
} 
Last but not least, in the empirical section, we propose a new simple indicator of quasi rents and compare the results with other models, where tests relate to revenues per head.

\section{Methodology and data description}

\subsection{Data}

Hamermesh (1993) discusses problems associated with collecting data for studies of labour demand. He notes that household level data can be inappropriate for studying labour market issues; instead data describing plants or firms is superior (p.63). The conclusions apply to the research on wage determinants, in particular where the focus is on firm-specific issues such as rent sharing. Following this, we follow the stream of empirical literature on transition economies, which rely on publicly available company level data on largest companies. Our data corresponds closely to that used by Grosfeld and Nivet (1999) for an earlier period. Also datasets used by Basu et al. (2000) and Christev and Fitzroy (2002) are similar, while the latter paper uses data from a survey, yet sampled from a similar population of Polish firms.

The source of our data is from a different project (with participation of one of the coauthors), financed by the Polish Committee for Scientific Research (grant 1H02C024-19), which was shared with us for the purpose of this study. The results of the earlier project (which focused on the group of privatised companies) are at present available in Polish, in an edited volume (Baltowski 2002).

The dataset was compiled by the Polish project team using all publicly available sources on Polish largest companies and the database of the Institute of Economics of the Polish Academy of Science, which is the basis of several published lists of largest companies' results. Where possible this was supplemented and checked using direct information publicly disclosed by the companies, and also available information by the Warsaw Stock Exchange and several lists published by journals and magazines, including Rzeczpospolita, Polityka, Gazeta Bankowa, Nowe Zycie Gospodarcze, Zycie Gospodarcze, Businessman.

Apart from standard type errors, several systemic problems were encountered by the Polish team during data processing. First, while in principle state companies were prevented from buying shares of other privatised companies in Poland, that 
neither applied to all privatisations (or semi-privatisations) resulting from bank-led restructuring programmes, nor to post privatisation ownership transfers, including for instance companies privatised via National Investment Funds programme. As a result, a number of 'privatised' companies are wrongly attributed to the private sector instead of state sector. Some of those links are not easy to detect, because of multi layered cross-company ownership. The dataset has been corrected for this type of error, where possible. Related problems relate to the distinction between minority and dominant class of owners. Also, sometimes companies are wrongly classified as 'de novo' private companies, either because they have been formally registered as a new company, as part of the privatisation proceedings, or because they are new companies created by other state-controlled firms. ${ }^{15}$ This relates in particular to companies privatised by employee buy-outs, i. e. by leasing (for details, see Mickiewicz and Baltowski, 2002). And last but not least, when compiling data for several years, one has to pay attention to the fact that some sources do not distinguish between individual companies and consolidated balances of capital groups with similar names. This has been checked for relevant companies, as compiling both categories into one time series would create a serious distortion in data.

As the data contain information about both the name of the company and location, we were able to match the data set with corresponding administrative units and subsequently with relevant regional labour market indicators available from the Polish Central Statistical Office. A particular problem we encountered was related to the fact that 82 out of 329 companies included in the sample are registered in Warsaw (25\%) and they in fact are split into two sub-categories: companies operating nationwide, and those where most of their operations are located in the capital city. Therefore, using information on individual companies, we identified 29 companies, for which most of operations (typically manufacturing production, but also hotels etc) are located in Warsaw. The remaining firms (53, equivalent to $16 \%$ of the sample) we label nation-wide. Those typically include both trade companies, retail networks in particular, but also manufacturing, where the majority of operations is spread across several locations. The chosen method to deal with this data problem was to attribute

\footnotetext{
${ }^{15}$ In our dataset that relates to three companies: Centertel, Lim and Polcomtel, which we classified as 'state- mixed'.
} 
national averages as relevant labour market indicators in the case of those companies labelled nation-wide.

\subsection{Descriptive statistics}

Here descriptive statistics are presented for selected variables in the data set.

The table below presents median values for the three ownership categories. Reported significance levels relate to non-parametric tests on the equality of medians.

$\underline{\text { Table 2. Median values for selected variables over 1999-2001 }}$

\begin{tabular}{llllll}
\hline Variable & All firms & $\begin{array}{l}\text { Private } \\
\text { de novo }\end{array}$ & Privatised & State Mixed & $\begin{array}{l}\text { State } 100 \% \\
\text { Treasury }\end{array}$ \\
\hline $\begin{array}{l}\% \text { change in } \\
\text { real wage }\end{array}$ & 8.56 & 6.15 & 10.30 & 9.26 & 6.26 \\
$\begin{array}{l}\% \text { change in } \\
\text { real total } \\
\text { revenue } \\
\% \text { change in } \\
\text { revenue / } \\
\text { employment } \\
\text { earnings before } \\
\text { taxes / revenue } \\
\text { net income / } \\
\text { revenue }\end{array}$ & 0.60 & $4.62 * * *$ & -0.21 & 2.23 & $-1.66^{* * *}$ \\
\hline
\end{tabular}

$* * *$ Significant at $0.001 ; * *$ Significant at $0.01 ; * * * *$ Significant at $0.05 ; \dagger$ Significant at 0.1 ${ }^{\text {a }}$ Significance levels relate to Pearson $\chi^{2}$ (continuity corrected) based on the non-parametric test on the equality of medians

Several conclusions follow immediately from Table 2. Wage growth is weakest both in the in the private de novo firms and in the ('non-reformed') state sector, albeit the reasons for that may be very different. Indeed, the results on wages contrast clearly with profitability: both gross and net measures of profitability are highest for the new private firms and lowest for the state sector, with both being consistently significant. This puts wage dynamics in perspective, as the crucial point is comparison between wage increase and financial results as that indicates the extent of rent sharing. From this perspective, the state sector looks very different from the new private firms.

While in the latter group moderate wage growth is matched by financial performance, in the former, similar wages increases are parallel to median net income rate being close to zero. 
Another noteworthy point is that differences in profitability are strongly related to differences in dynamics of revenue: in the period we consider, the state sector was also characterised by the lowest revenue dynamics. In this case, contrast between those two ownership groups is even more significant.

Also, interesting differences relate to revenue per employee. While, de novo sector is characterised by highest dynamics of revenues, it is not so in relation to revenue per employee. Here, dynamics are higher in the privatised sector. This clearly results from different employment dynamics (i.e. the denominator). The de novo sector is simply more efficient in employment creation and preservation than both the state and the privatised sector. This exemplifies why revenue per head is not a good indicator of performance, in spite the fact that it is widely used as such in empirical research on transition economies. On the other hand, the difference between the revenue per head and sectoral wage may still be valid as a measure of available quasi rent, as argued by Van Reenen (1996).

In this category, the 'unreformed' state sector is still the worst performer, while privatised firms score best, but mostly due to labour shedding, as comparison with dynamics of total revenue easily reveals.

\subsection{Variable description}

This section presents the variables used in the model. Description is presented in Table 3 below. 
Table 3. Description of available variables

\begin{tabular}{|c|c|}
\hline Description of variable & Details / comments \\
\hline \multicolumn{2}{|r|}{ Dependent variable } \\
\hline $\begin{array}{l}\text { l_rwage } \\
\text { Logarithm of real wages }\end{array}$ & $\begin{array}{l}\text { Logarithm of (average monthly wage in zlotys/consumer } \\
\text { price index).Data available for 1996, 1998, 1999, 2000, } \\
\text { 2001. CPI }{ }^{16} \text { : Central Statistical Office indicator }\end{array}$ \\
\hline \multicolumn{2}{|r|}{ Internal characteristics } \\
\hline $\begin{array}{l}\text { l_employ: Logarithm of } \\
\text { number of employees }\end{array}$ & Available for $1996-2001$ \\
\hline $\begin{array}{l}\text { l_rtremp: Logarithm of (real } \\
\text { revenue / employment) }\end{array}$ & $\begin{array}{l}\text { Logarithm of [(total revenue in million zlotys/ consumer } \\
\text { price index) / employment ] } \\
\text { Available for 1996-2001 }\end{array}$ \\
\hline $\begin{array}{l}\text { ebt_rev: Earnings before } \\
\text { taxes/ revenue }\end{array}$ & Available for $1996-2001$ \\
\hline $\begin{array}{l}\text { ntin_rev: Net income/ } \\
\text { revenue }\end{array}$ & Available for $1996-2001$ \\
\hline $\begin{array}{l}\text { state_trea100: State firm } \\
\text { (dummy variable) }\end{array}$ & State ownership: entirely owned by the State Treasury \\
\hline $\begin{array}{l}\text { state_mix: State firm with } \\
\text { mixed ownership } \\
\text { (dummy variable) }\end{array}$ & $\begin{array}{l}\text { Majority state ownership with other owners present: a } \\
\text { firm with the majority of shares owned by the treasury, } \\
\text { or a company, where majority of shares is held by a state } \\
\text { firm; the category includes also few firms controlled by } \\
\text { local governments }\end{array}$ \\
\hline $\begin{array}{l}\text { privatis: } \text { Priviatised firm } \\
\text { (dummy variable) }\end{array}$ & $\begin{array}{l}\text { A previously state-owned company, which was no longer } \\
\text { state-owned by } 2001\end{array}$ \\
\hline $\begin{array}{l}\text { de_novo: De novo private } \\
\text { firm (dummy variable) }\end{array}$ & $\begin{array}{l}\text { A new private company, i.e. which is neither state owned } \\
\text { nor was ever state owned }\end{array}$ \\
\hline \multicolumn{2}{|c|}{ External characteristics (Central Statistical Office data) } \\
\hline $\begin{array}{l}\text { l_rswage: Logarithm of real } \\
\text { sectoral wages }\end{array}$ & $\begin{array}{l}\text { Logarithm of (average monthly wage in zlotys/consumer } \\
\text { price index). Data available for 1996-2001, two digit } \\
\text { NACE industrial sectors }\end{array}$ \\
\hline $\begin{array}{l}\text { l_unsu_n: Log of } \\
\text { unemployment rate, } \\
\text { province level }\end{array}$ & $\begin{array}{l}\text { From labour force surveys (ILO definition) } \\
\text { Unemployment rate at the provincial level; } 17 \text { (new) } \\
\text { provinces. Mid year. Available for: 1995-2000 }\end{array}$ \\
\hline $\begin{array}{l}\text { l_unre_s: Log of registered } \\
\text { unemployment rate, sub- } \\
\text { regional level }\end{array}$ & $\begin{array}{l}\text { Sub-regions: } 43 \text { units, including large cities, as defined } \\
\text { by the Central Statistical Office of Poland. End of year. } \\
\text { Available for: } 1998-2000\end{array}$ \\
\hline $\begin{array}{l}\text { LTE: } \text { Proportion of long } \\
\text { term unemployment in total } \\
\text { employment, sub-regional }\end{array}$ & $\begin{array}{l}\text { Short term: less than one year. End of year } \\
\text { Available for: } 1998-2000\end{array}$ \\
\hline $\begin{array}{l}\text { l_emp_n: Log of } \\
\text { employment rate, province }\end{array}$ & $\begin{array}{l}\text { Mid year. Available for: 1995-2000; ; } 17 \text { (new) } \\
\text { provinces }\end{array}$ \\
\hline
\end{tabular}

\footnotetext{
${ }^{16}$ Other studies have also used CPI as a deflator, such as Christofides and Oswald (1992) and Abowd and Lemieux(1993).
} 


\section{4 Econometrics:details}

While we employ other techniques to provide comparability with some earlier results, the focus of estimation is on Generalised Method of Moments. In particular, Judson and Owen (1999) supports the conclusion that the estimation method originated by Arellano and Bond (1991) is superior as compared with feasible alternatives for panels with a short time dimension. The GMM estimator is robust in that it does not require information of the exact distribution of the disturbances and is instrumental in combating the problems associated with potential endogenity. However, the panel we have at our disposal is particularly short- and furthermore it shrinks to three time points as soon as we apply first differences. While Christev and FitzRoy (2002) were able to estimate Arellano-Bond model on the data of similar dimension, it turned out to be problematic in our case. We adopt an approach, where we apply several available techniques including the dynamic specification, and report the results, using specification tests to indicate which models may be the most efficient.

We made several informed choices in the specification choice of the model. Firstly, following recommended methodology, we focused on first differences to alleviate possible problems related to individual fixed effects. Secondly, while we follow a standard practice of using revenues per employee, while controlling for sectoral wages, when testing for rent sharing, we also combine a simple indicator of quasi rents (see below). Also, we adopted a restrained approach in our choice of ownership categories. Given that the relatively small samples of enterprises are available for transition economies, when too many distinctions are introduced, the corresponding groups are becoming small and one can notice volatility of results between various empirical studies. Therefore we choose the four ownership categories, described in Tables 1 and 2: state companies, state companies with minority private ownership, privatised companies and de novo firms. Another critical element of wage setting relates to the response of wages to regional labour market conditions. As argued above, we extend the analysis here, as compared with earlier studies, both by correcting for companies, which operate nation-wide while being registered in the capital city (see above). We also used several alternative 
labour market indicators, which include survey unemployment, registered unemployment and employment (not reported). ${ }^{17}$

\section{Results and discussion}

We start with the econometric design copied from Grosfeld and Nivet (1999), as their results are based on the same set of companies. The direct comparison is presented in columns (1) and (2) of Table 4 below. They show random effects estimations, which Grosfeld and Nivet (1999) choose as their preferred estimation method, as justified by Hausman test against fixed effects (within) model. Interestingly, the signs of the coefficients are the same and the size of the coefficients is in a similar range, apart from the impact of regional unemployment, where our results indicate a stronger effect on wage dynamics.

\footnotetext{
${ }^{17}$ In addition we tested for the hypothesis formulated by Nickell and Wadhwani (1990) distinguishing between long term and short term unemployment. We were unable to confirm it.
} 
Table 4. Wage equations; comparison with Grosfeld and Nivet (1999). Dependent variable: $\Delta l$ rwage

\begin{tabular}{|c|c|c|c|c|c|c|}
\hline & $\begin{array}{l}(1) \\
1991- \\
1994 \\
\text { Random } \\
\text { Effects } \\
\text { GLS }^{\mathrm{a}}\end{array}$ & $\begin{array}{l}(2) \\
1998-2001 \\
\text { Random } \\
\text { Effects } \\
\text { GLS }\end{array}$ & $\begin{array}{l}(3) \\
1998- \\
2001 \\
\text { Fixed } \\
\text { Effects } \\
\text { (within) }\end{array}$ & $\begin{array}{l}(4) \\
1998-2001 \\
\text { Pooled } \\
\text { OLS }^{b}\end{array}$ & $\begin{array}{l}\text { (5) } \\
\text { Arellano-Bond } \\
\text { GMM } \\
\text { Dynamic } \\
\text { Estimation } \\
\text { (one stage) }\end{array}$ & $\begin{array}{l}(6) \\
\text { Arellano- } \\
\text { Bond } \\
\text { GMM } \\
\text { Dynamic } \\
\text { Estimation } \\
\text { (two stage) }\end{array}$ \\
\hline Constant & $\begin{array}{l}0.097^{*} \\
(0.039)\end{array}$ & $\begin{array}{l}0.047 \\
(0.035)\end{array}$ & $\begin{array}{l}0.020 \\
0.040\end{array}$ & $\begin{array}{l}0.055^{*} \\
(0.022)\end{array}$ & $\begin{array}{l}-0.047 \\
(0.076)\end{array}$ & $\begin{array}{l}-0.058 \\
(0.077)\end{array}$ \\
\hline$\Delta \mathrm{l} \_$rtremp & $\begin{array}{l}0.140 * * \\
(0.020)\end{array}$ & $\begin{array}{l}0.188 * * * \\
(0.041)\end{array}$ & $\begin{array}{l}0.232 * * * \\
(0.054)\end{array}$ & $\begin{array}{l}0.175^{* * *} \\
(0.043)\end{array}$ & $\begin{array}{l}0.170 * * \\
(0.070)\end{array}$ & $\begin{array}{l}0.243^{*} \\
(0.105)\end{array}$ \\
\hline $\begin{array}{l}\Delta \\
1 \text { rswage }\end{array}$ & $\begin{array}{l}0.894 * * \\
(0.052)\end{array}$ & $\begin{array}{l}0.766^{* * *} \\
(0.195)\end{array}$ & $\begin{array}{l}0.948 * * * \\
(0.231)\end{array}$ & $\begin{array}{l}0.705^{* * *} \\
(0.153)\end{array}$ & $\begin{array}{l}-0.332 \\
(0.710)\end{array}$ & $\begin{array}{l}-0.349 \\
(0.862)\end{array}$ \\
\hline $\bar{\Delta}$ & $-0.031^{*}$ & $-0.227 \dagger$ & -0.170 & $-0.255 \dagger$ & -0.120 & -0.156 \\
\hline${ }_{1}^{1} \mathrm{c}$ unsu_n $\mathrm{n}_{\mathrm{t}-}$ & $(0.014)$ & $(0.123)$ & $(0.147)$ & $(0.146)$ & $(0.226)$ & $(0.217)$ \\
\hline $\begin{array}{l}\text { Wald } \chi^{2} \\
\text { F }\end{array}$ & - & $109.62 * * *$ & $32.53 * * *$ & $72.27 * * *$ & & \\
\hline $\begin{array}{l}\text { Sargan } \\
\text { test: } \chi^{2} \\
\text { (over- } \\
\text { identifying } \\
\text { restrictions) }\end{array}$ & & & & & $79.90 * * *$ & $28.14 * * *$ \\
\hline $\mathrm{R}^{2}$ & 0.373 & 0.143 & 0.145 & 0.143 & & \\
\hline $\mathrm{N}$ & 678 & 587 & 587 & 587 & 311 & 311 \\
\hline
\end{tabular}


In columns (3)-(6) we present the results of alternative specification methods, that is fixed effects, pooled ordinary least squares and Arellano-Bond GMM. The most consistent result relates to the impact of revenue per employee, which is consistently highly significant, with the size of the effects varying from 0.170 to 0.243 , depending on the estimation method. The result can be interpreted as evidence of rent sharing behaviour, with the effect being marginally stronger than for the early transition period (0.140 in Grosfeld and Nivet 1999). The effect of regional unemployment is consistently negative, but less significant. In specification (4) where we correct standard errors for possible interdependence of observation within regions, the significance level is cut from below the 5\% threshold (not reported) to below the $10 \%$ threshold. Finally, sectoral wages appear to correlate significantly with enterprise level wages, apart from the dynamic specifications.

Comparing the estimation methods, one can see that random effects, fixed effects and pooled OLS result in relatively similar estimations. The dynamic specifications seem to differ more, nevertheless in both one stage and two stage specifications, and the Sargan test strongly rejects validity of the models. The value of $\chi^{2}$ is greatly reduced when the two stage procedure is used, yet not enough; the test still strongly rejects the validity of the second model. Also, estimations of the autoregressive term are not robust (which we did not report). The problem with Arellano-Bond specifications may results from the fact that we loose considerable number of observations. The reported number of observations is not only reduced by the fact that we lost one time point for the lagged dependent variable, but also because of the missing data problems in earlier time points used for instruments. One possible path would be to use maximum likelihood methods to impute missing values, for instance using expected maximisation (EM) procedure. That would possibly result with better estimates of coefficients, but unfortunately, also with inflated standard errors, with no clear method of correction. ${ }^{18}$

Thus, unlike Christev and Fitzroy (2002), who were had more success with their survey data and successfully estimated the Arrelano-Bond model for their panel of similar dimensions, we simply fail with the dynamic specification and propose to rely on simpler panel methods, as do Grosfeld and Nivet (1999).

${ }^{18}$ See classic discussion in Griliches (1986). Also a recent overview is offered by Allison (2002). 
Yet one lesson from the dynamic specifications (columns (5) and (6)) are important: even if dynamic models are deficient, they indicate that coefficients of sectoral wages are not robust for this change in specification. More than one reason for this is possible. One simple correction we may try, is to assume that the significance of sectoral wages in columns (1)-(4) is forced by the choice specification, namely, as the variable may capture time effects, which were not directly accounted for so far.

Following this idea, we adjust for time effects. Results are presented in columns (1)(3) in Table 5 below.

Table 5. Wage equations with time effects. Dependent variable: $\Delta l$ rwage

\begin{tabular}{|c|c|c|c|c|c|c|}
\hline & $\begin{array}{l}(1) \\
1998-2001 \\
\text { Random } \\
\text { Effects } \\
\text { GLS }\end{array}$ & $\begin{array}{l}(2) \\
1998-2001 \\
\text { Fixed } \\
\text { Effects } \\
\text { (within) }\end{array}$ & $\begin{array}{l}(3) \\
1998-01 \\
\text { Pooled } \\
\text { OLS }^{\mathrm{a}}\end{array}$ & $\begin{array}{l}(4) \\
1998-2001 \\
\text { Random } \\
\text { Effects } \\
\text { GLS }\end{array}$ & $\begin{array}{l}(5) \\
1998-2001 \\
\text { Fixed } \\
\text { Effects } \\
\text { (within) }\end{array}$ & $\begin{array}{l}(6) \\
1998-2001 \\
\text { Pooled } \\
\text { OLS }^{\mathrm{a}}\end{array}$ \\
\hline Constant & $\begin{array}{l}0.071 \\
(0.052)\end{array}$ & $\begin{array}{l}0.050 \\
(0.063)\end{array}$ & $\begin{array}{l}0.074 \\
(.087)\end{array}$ & 0.072 & 0.056 & $\begin{array}{l}0.073 \\
(0.087)\end{array}$ \\
\hline$\Delta$ quasi_rent & - & - & - & $\begin{array}{l}0.187 * * * \\
(0.041)\end{array}$ & $\begin{array}{l}0.227 * * * \\
(0.189)\end{array}$ & $\begin{array}{l}0.176^{* * *} \\
(0.042)\end{array}$ \\
\hline$\Delta \mathrm{l} \_$rtremp & $\begin{array}{l}0.188 * * * \\
(0.041)\end{array}$ & $\begin{array}{l}0.235^{* * *} \\
0.054\end{array}$ & $\begin{array}{l}0.174 * * * \\
(0.043)\end{array}$ & - & - & - \\
\hline$\Delta$ 1_rswage & $\begin{array}{l}-0.141 \\
(0.444)\end{array}$ & $\begin{array}{l}0.599 \\
(0.591)\end{array}$ & $\begin{array}{l}-0.308 \\
(0.287)\end{array}$ & - & - & - \\
\hline$\Delta \mathrm{l} \_$unsu_n $\mathrm{n}_{\mathrm{t}-\mathrm{l}} \mathrm{b}$ & $\begin{array}{l}-0.187 \\
(0.152)\end{array}$ & $\begin{array}{l}-0.194 \\
(0.190)\end{array}$ & $\begin{array}{l}-0.193 \\
(0.109)\end{array}$ & $\begin{array}{l}-0.187 \\
(0.151)\end{array}$ & $\begin{array}{l}-0.165 \\
(0.189)\end{array}$ & $\begin{array}{l}-0.193 \dagger \\
(0.220)\end{array}$ \\
\hline Wald $\chi^{2}$ & $116.33^{* * *}$ & & & $116.64 * * *$ & & \\
\hline $\begin{array}{l}\mathrm{F} \\
\mathrm{R}^{2} \\
\text { Hausman } \\
\text { test }\end{array}$ & 0.154 & $\begin{array}{l}19.66^{* * *} \\
0.147\end{array}$ & $99.60 * * *$ & $\chi^{0.154} \chi^{2}(4$ & $\begin{array}{l}24.01 * * * \\
0.153 \\
=1.67\end{array}$ & $\begin{array}{l}122.54 * * * \\
0.154\end{array}$ \\
\hline $\mathrm{N}$ & 587 & 587 & 587 & 587 & 587 & 587 \\
\hline
\end{tabular}

$* * *$ Significant at $0.001 ; * *$ Significant at $0.01 ; * * * *$ Significant at $0.05 ; \uparrow$ Significant at 0.1

${ }^{a}$ Robust standard errors; corrected for possible interdependence of observations within the same provinces (clusters)

${ }^{\mathrm{b}}$ Survey unemployment rates are mid year values (see Table 4); therefore one year lag is used 
Indeed, coefficients on sectoral wages become insignificant and highly unstable, as they no longer capture time effects. Similarly, the regional unemployment variable is insignificant for columns $1-5$, and is only $10 \%$ significant for column 6 (i.e. when using the pooled OLS technique), yet - unlike sectoral wages - both the signs and magnitude of effects remain similar to earlier specifications. More positively, the coefficients on revenue per employee remain practically unchanged and highly significant - again, we have consistent evidence, which can be interpreted as evidence of rent sharing.

Inconsistent results on sectoral wages in the adjusted specification and negative signs of the coefficients suggest that the variable may be better used differently. Namely, as argued above, the ratio of revenue per employee over sectoral wage, may be a good proxy for quasi rents. The latter indicates the opportunity cost outside the company and the former is an indicator of ability to pay. If correct, the argument could explain the negative sign of the real sectoral wage coefficient: lower sectoral wages would mean higher relative rents. Correspondingly, we construct a new variable, which in logarithmic form is simply given as: quasi_rent $=\boldsymbol{l}$ _rtremp $-\boldsymbol{l} \_$rswage. The results are reported in columns (4)-(6) of Table 5. The new indicator performs as expected. Coefficients are highly significant and similar to those estimated for revenue per head. Also, results on unemployment are not affected.

Finally, we compare the different estimation methods. Applying the Hausman test to random versus fixed effects models, i.e. to equations (4) and (5) in Table 5, we cannot reject the hypothesis that coefficients are the same, as the test statistic is highly insignificant $\left(\chi^{2}(4)=1.67\right)$. On the basis of this test we recommend the random effects model. A similar result was obtained by Grosfeld and Nivet (1999), where the Hausman test produces the same effect. Despited the short time dimension of the model, the potential problems resulting from individual effects were clearly alleviated by first differencing of variables.

At this junction, we wish to explore further the characteristics of rent sharing, focusing on two issues: /1/ asymmetry, and /2/ dissimilarity in behaviour of different ownership categories of firms. 
We start with asymmetry. In Table 6 below we allow for difference in quasi-rent elasticity of wages, by introducing a supplementary variable. This new variable $\Delta$ quasi_rent_in - takes a value of zero for all observations where $\Delta$ quasi rent $<\boldsymbol{0}$, and has a value equal to $\Delta$ quasi rent where $\Delta$ quasi rent $>0$. By doing this, we introduce a diiferential coefficient for those observations, where change was positive. As before, we apply both the fixed and random effects model, and find the latter preferable, as differences in coefficients appear insignificant based on Hausman test.

Table 6. Asymmetry. Dependent variable: $\Delta l$ rwage $^{\mathrm{a}}$

\begin{tabular}{lll}
\hline & $\begin{array}{l}(1) \\
1998-2001 ; \text { Random } \\
\text { Effects GLS }\end{array}$ & $\begin{array}{l}(2) \\
1998-2001 ; \text { Fixed } \\
\text { Effects (within) }\end{array}$ \\
\hline Constant & $0.091(0.053) \dagger$ & $0.067(0.065)$ \\
$\Delta$ quasi_rent & $0.273(0.062)^{* * *}$ & $0.284(0.083)^{* * * *}$ \\
$\Delta$ quasi_rent_in & $-0.188(0.102) \dagger$ & $-0.131(0.146)$ \\
$\Delta$ 1_unsu_n $\mathrm{n}_{\mathrm{t}-\mathrm{b}}$ & $-0.189(0.151)$ & $-0.162(0.189)$ \\
$\mathrm{W}$ ald $\chi^{2}$ & $120.35^{* * *}$ & $19.35^{* * *}$ \\
$\mathrm{~F}$ & 0.160 & 0.158 \\
$\mathrm{R}^{2}$ & $\chi^{2}(5)=1.79$ & 587 \\
Hausman test & 587 & \\
$\mathrm{~N}$ & & \\
\hline$* * *$ Significant at $0.001 ; * *$ Significant at $0.01 ; * * * *$ Significant at $0.05 ; \dagger$ Significant at 0.1 \\
a Time effects included \\
${ }^{\mathrm{b}}$ Survey unemployment rates are mid year values (see Table 4); therefore one year lag is used
\end{tabular}


The results reveal that indeed, the elasticity of wages differs, when the increase in quasi rent is separated from the decrease. For firms with decreasing quasi rents, the elasticity of wages is 0.273 , for those with increasing it falls to $0.085=0.273-0.188$. This is a positive finding, as it indicates that wage pressure may be less of a problem than indicated by aggregate results. Companies in which performance is improving are capable of increasing retained earnings and finance further development, as elasticity of wages is relatively low and therefore cost dynamics are kept under control. On the other hand, wage pressure seems to be responsive to deterioration in performance, which may indicate that it is not only wages but also employment, which ranks high in employees' utility function. Interestingly, in this respect the results differ from those obtained by Grosfeld and Nivet (1999) for the earlier transition period. ${ }^{19}$ While their estimation of elasticity for firms with increasing quasi rents is very similar to ours $(0.166)$, they obtain a very different result for those, where quasi rents are decreasing: for their sample it is very low (0.018) and insignificant. The change in behaviour may reflect growing concerns of the employees about their employment, given the deterioration in labour market conditions. This particular effect however is not well captured by regional crosssection in labour market indicators - when we tested for different coefficients in elasticity of regional unemployment, we found virtually no difference between firms with increasing and decreasing quasi rents.

Last but not least, we wish to explore, if wage behaviour differs across ownership sectors. We distinguish between four ownership categories: (i) companies entirely owned by the state treasury, (ii) companies with majority state shares, (iii) companies privatised until 2001, (iv) new private companies. All tests are presented in Table 7.

\footnotetext{
${ }^{19}$ Grosfeld and Nivet (1999) use revenue per employee. For reasons argued before, we prefer our new simple measure of quasi rents, but empirically it makes little difference.
} 
Table 7. Ownership. Dependent variable: $\Delta l$ rwage $e^{\mathrm{a}}$

\begin{tabular}{|c|c|c|c|c|c|c|}
\hline & $\begin{array}{l}(1) \\
1998-2001 \\
\text { Random Effects } \\
\text { GLS. } \\
\text { All }^{\mathrm{c}}\end{array}$ & $\begin{array}{l}(1 \mathrm{a}) \\
\text { Wald test } \\
\text { for } \\
\text { quasi_rent } \\
: \\
\text { privatised } \\
\text { v. other } \\
\text { groups }^{\mathrm{c}}\end{array}$ & $\begin{array}{l}(2) \\
1998-2001 \\
\text { Random } \\
\text { Effects } \\
\text { GLS. } \\
\text { De novo } \\
\text { firms }\end{array}$ & $\begin{array}{l}(3) \\
1998-2001 \\
\text { Random } \\
\text { Effects } \\
\text { GLS. } \\
\text { Privatised }\end{array}$ & $\begin{array}{l}\text { (4) } \\
\text { 1998-2001 } \\
\text { Random } \\
\text { Effects } \\
\text { GLS. } \\
\text { State } \\
\text { (Mixed) }\end{array}$ & $\begin{array}{l}(5) \\
1998-2001 \\
\text { Random } \\
\text { Effects } \\
\text { GLS. } \\
\text { State } \\
(100 \%)\end{array}$ \\
\hline Constant & $0.076(0.051)$ & & $\begin{array}{l}-0.115 \\
(0.171)\end{array}$ & $\begin{array}{l}-0.021 \\
(0.109)\end{array}$ & $\begin{array}{l}-0.025 \\
(0.123)\end{array}$ & $\begin{array}{l}0.224 \\
(0.061)^{* *} \\
*\end{array}$ \\
\hline $\begin{array}{l}\Delta \text { quasi_r } \\
\text { ent_dn }\end{array}$ & $\begin{array}{l}0.341 \\
(0.102)^{* * *}\end{array}$ & $\begin{array}{l}\chi^{2}(1)=11.0 \\
3 * * *\end{array}$ & $\begin{array}{l}0.395 \\
(0.158)^{* *}\end{array}$ & & & \\
\hline $\begin{array}{l}\Delta q u a s i \_r \\
\text { ent_ps }\end{array}$ & $-0.063(0.071)$ & - & & $\begin{array}{l}-0.105 \\
(0.074)\end{array}$ & & \\
\hline $\begin{array}{l}\Delta \text { quasi_r } \\
\text { ent_mx }\end{array}$ & $0.239(0.097)^{* *}$ & $\begin{array}{l}\chi^{2}(1)=6.44 \\
* *\end{array}$ & & & $\begin{array}{l}0.213 \\
(0.091)^{*}\end{array}$ & \\
\hline $\begin{array}{l}\Delta \text { quasi_r } \\
\text { ent_st }\end{array}$ & $\begin{array}{l}0.283 \\
(0.058) * * *\end{array}$ & $\begin{array}{l}\chi^{2}(1)=15.2 \\
7 * * *\end{array}$ & & & & $\begin{array}{l}0.230 \\
(0.047)^{* *} \\
*\end{array}$ \\
\hline $\begin{array}{l}\Delta \\
\text { l_unsu_n }_{\mathrm{t}-1} \mathrm{n}\end{array}$ & $-0.196(0.145)$ & & $\begin{array}{l}0.567 \\
(0.571)\end{array}$ & $\begin{array}{l}0.079 \\
(0.304)\end{array}$ & $\begin{array}{l}0.039 \\
(0.361)\end{array}$ & $\begin{array}{l}-0.668 \\
(0.169)^{* *} \\
*\end{array}$ \\
\hline Wald $\chi^{2}$ & $139.15 * * *$ & & $16.55^{* *}$ & $34.70 * * *$ & $17.72 * * *$ & $115.16^{* * *}$ \\
\hline $\mathrm{R}^{2}$ & 0.181 & & 0.105 & 0.176 & 0.191 & 0.356 \\
\hline $\mathrm{N}$ & 587 & & 127 & 168 & 80 & 212 \\
\hline
\end{tabular}


First we restrict ourselves to a comparison of differences in quasi rent elasticity of wages. Again, we separate corresponding coefficients by replacing $\Delta q u a s i$ rent by four new variables, which take values of zero for three of the ownership categories and equal the value of $\Delta q u a s i$ rent for one selected category. Wald test for differences in coefficients reveal that elasticity in the privatised sector differs significantly from all other ownership sectors. Unlike the other, there is hardly any evidence of rent sharing in the privatised sector - coefficients are low and insignificant. Further inspection reveals that a fault line is not between companies, which are controlled by the state, and those where privatisation process started: difference between the companies entirely owned by the Treasury and those with some minority private ownership is highly insignificant and coefficients are far more similar than those between privatised and mixed state ownership. In contrast, the Wald test for the two latter groups is undoubtedly significant (see Table 7, column 1a). Finally, there is strong indication of rent sharing in de novo sector. Yet, before paradoxically concluding that de novo sector is similar to the state sector, we wish to run separate estimations for all ownership sectors to explore if there are other differences beyond quasi rent elasticity of wages. The results are in columns (2)-(5) of Table 7. 
The exercise turns out to be productive, as several additional conclusions can be drawn, including comparison with Grosfeld and Nivet (1999), who use a similar design (however: (i) there is no de novo group in their sample, as it relates to the early transition period, (ii) our groupings within the state sector differ). Looking both at Wald statistics and $\mathrm{R}^{2}$ it is easy to notice that wage behaviour of state companies is clearly most uniform and consistent. Interestingly, that confirms Grosfeld and Nivets' (1999) findings for the early transition period. Furthermore, the state sector reveals two additional characteristics. First, similarly to Grosfeld and Nivet (1999), regional unemployment coefficient is highly significant, while it plays no role for the other ownership sectors. The unemployment elasticity of wages in the state sector is remarkably high, at -0.668 . Second, the value of the intercept term is best estimated for the state sector, it is also much higher than for the other sectors. In this respect, comparison with de novo sector is particularly interesting. While quasi rent elasticity of wages in de novo sector is slightly higher than in the state sector, the former exhibits the strongest trend in wage growth, independent of ability to pay. Clearly, a different wage setting mechanism is operating.

In the state sector, wage pressure seems to be strong, and is also highly responsive both to regional unemployment and to availability of quasi rents. In the new private companies, the basic trend in wage increases is insignificant but they respond stronger to quasi rents.

However, the most dramatic result relates to privatised sector, where we can notice a dramatic difference in wage behaviour as compared with the state sector. There is hardly any evidence of rent sharing in the privatised sector. In this respect, we were able to confirm earlier results by Grosfeld and Nivet (1999). The positive results of privatisation still exist, even ten years after the early stages of economic reforms. 


\section{Conclusions}

Our motivation was to see if the difference between new and old firms in wage setting dominates the state - privatised cross section. The answer seems to be that both distinctions are important. When we estimate separate equations, a clear pattern in wages setting emerges.

Wage dynamics in state firms are highly sensitive to regional unemployment, while this finding disappears in the private sector. On the other hand, in both state firms and new private firms, quasi rent elasticity of wages is substantial. That contrasts with the behaviour of privatised companies, where the rent sharing pattern is broken. What increases our confidence in this last effect is the fact that similar results were reported by Grosfeld and Nivet (1999) for the earlier transition period.

Two more general lessons are worth reporting. First, we hope that our proposed new simple measure of quasi rent may be effectively applied in the future, as it produces consistent results. Second, the sharp contrast in employment elasticity between ownership sectors indicates that wage curve parameters may be evolving over time in countries, which undergo ownership transformations. In particular, we may expect the unemployment elasticity of wages to decrease as a result of privatisation process.

\section{Bibliography}

Abowd, J., and Lemieux, T., 1993, The effects of product market competition on collective bargaining agreements: the case of foreign competition in Canada, Quarterly Journal of Economics, 108, 983-1014.

Adamchik, V. and Bedi, A., 2000,Wage Differentials between the Public and the Private Sectors; Evidence from an Economy in Transition, Labour Economics, 7, 203 224.

Allison, P., 2002, Missing Data, (Sage Publications Thousand Oaks).

Arellano, M., and Bond, S., 1991, Some tests of specification for panel data: Monte Carlo evidence and an application to employment equations, Review of Economic Studies, 58, 277-297.

Balcerowicz, L., 1995, Socialism, Capitalism, Transformation, (Central European University Press, Budapest).

Baltowski, M. (ed.), 2002, Przedsiebiorstwa Sprywatyzowane w Gospodarce Polskiej, (PWN, Warszawa)..

Basu, S., Estrin, S., and Svejnar, J., 2000, Employment and wages in enterprises under communism and in transition: evidence from Central Europe and Russia, WDI Working paper, 114b..

Blanchard, O., 1997, The Economics of Post-Communist Transition,( Clarendon Press, Oxford) . 
Blanchflower, D, G., 1990, Fear, unemployment and pay flexibility, Mimeo. Blanchflower, D, G., 2001, Unemployment, well-being and wage curves in Eastern and Central Europe, Journal of Japanese and International Economics, 15, 364-402.

Boeri, T., Burda, M., Kollo, J., 1988, Mediating the transition: Labour markets in Central and Eastern Europe, (CEPR, London)..

Brainerd, E., 2002, Five years after: the impact of mass privatisation on wages in Russia, Journal of Comparative Economics, 160-90.

Cahuc, P., and Gianella, C., Goux D., and Zylerberg, A., 2002, Equalizing wage differences and bargaining power: evidence from a panel of French firms, CEPR Discussion Paper No. 3510.

Carlin, W., S. Estrin, M. Shaffer, 1999, Measuring Progress in Transition and Towards EU Accession: A Comparison of Manufacturing Firms in Poland, Romania and Spain, University of Michigan, William Davidson Institute Working Paper, No. 224.

Carlin, W., S. Fries, M. Schaffer, P. Seabright, 2001, Competition and Enterprise Performance in Transition Economies. Evidence from a Cross-country Survey, University of Michigan, William Davidson Institute Working Paper, No. 376.

Christev, A and Fitzroy, F., 2002, Employment and wage adjustment: insideroutsider control in a Polish privatisation panel study, Journal of Comparative Economics, 30, 251-275.

Christofides, L., and Oswald, A., 1992, Real wage determination and rent sharing in collective bargaining agreements, The Quarterly Journal of Economics, 985-1002.

Demsetz, H., and Lehn, K., 1985, The Structure of Corporate Ownership: Causes and Consequences, Journal of Political Economy, Vol. 93, 1155-1177.

Demsetz, H. and Villalonga, B., 2001, Ownership Structure and Corporate Performance, Journal of Corporate Finance, Vol. 7, 209-233.

Djankov, S. and P. Murrell, 2002, Enterprise Restructuring in Transition: A Quantitative Survey", Journal of Economic Literature, 40, 3, 739-792.

Dong, X., 1998,Employment and wage determination in China's rural industry: investigation using 1984-90 Panel data, Journal of Comparative Economics, 26, 485502.

Duffy, F., and Walsh, P., 2001, Individual pay and outside options: evidence from the Polish Labour Force Survey, IZA Discussion paper, No. 295.

Fakhfakr, F., and Felix FitzRoy, F., 2002, Basic wages and firm characteristics: rent sharing in French manufacturing," University of St Andrew's, CRIEFF discussion paper, DP0203.

Furubotn, E., 2001, The New Institutional Economics and The Theory of the Firm, Journal of Economic Behaviour and Organization, 45, 133-153.

Goux, D., and Maurin, E., 1999, Persistence of inter-industry wage differentials: a re-examination using matched worker firm panel data, Journal of Labour Economics, $17,3,492-533$.

Gregg, P., and Machin, S., 1992, Unions, the demise of the closed shop and wage growth in the 1980's, Oxford Bulletin of Economics and Statistics, 54, 53-71.

Griliches, Z., Economic Data Issues, 1986, in: Z. Griliches and M. Intriligator eds., Handbook of Econometrics, (Elsevier Science Publishers)Vol. III, 605-654.

Grosfeld, I., and Nivet., J., 1999, Insider power and wage setting in transition: evidence from a panel of large Polish firms, 1998-94, European Economic Review , 43, 1137-1147. 
Hamermesh, S., 1993, Labor Demand (Princeton University Press)..

Harris, R., and Todaro, M., 1970, Migration, unemployment and development: a two sector analysis, American Economic Review, 60, 126-142.

Haskel, J., and Symanksi, S., 1993, Privatisation, liberalisation, wages and employment: theory and evidence for the UK, Economica, 60, 161-82.

Havrylyshyn, O., and McGettigan, D., 1999, Privatisation in transition countries: evidence for the first decade, IMF, Economic issue, 18.

Hildreth, A., and Oswald, A., 1997, Rent sharing and wages: evidence from company and establishment panels,Journal of Labour Economics, 15, 20, 318-337,

Holmund, B., and Zetterberg, J., 1991, Insider effects in wage determination: evidence from five countries, European Economic Review, 35, 1009-34..

Jones, D., 1998, Economic effects of privatisation-evidence from a Russian Panel," Comparative Economic Studies, Vol. 40, 75-102.

Johnson, S., D. Kaufmann, A. Shleifer, 1997, Politics and Entrepreneurship in Transition Economies, Working Paper, William Davidson Institute, University of Michigan Business School, No. 57.

Judson, R., and A. Owen, 1999, Estimating Dynamic Panel Data Models: A Guide for Macroeconomists, Economics Letters, 65, 9-15.

Kornai, J., 1995, Transformational Recession: The Example of Hungary, in: C. Saunders (ed.), Eastern Europe in Crisis and the Way Out, (Macmillan, Haundmills).

Lee, Y., 1999, Wages and employment in China's SOE's, 1980-1994:

Corporatisation, market development and insider forces, Journal of Comparative Economics, 27, 702-729.

Lehmann, H., and Wadsworth, J., 2000, Tenures that shook the world: worker turnover in Russia, Poland and Britain, Journal of Comparative Economics, 28, 639664.

Lindbeck, A., and Snower, D., 1987, The insider-outsider theory of employment and unemployment, (The MIT Press, Cambridge, London, England).

Mickiewicz, T., Baltowski, M., 2003, All Roads Lead to Outside Ownership: Polish Piecemeal Privatisation, in: D. Saal and D. Parker, eds., Handbook of Privatisation, (Edward Elgar, Cheltenham), Chapter 19.

Nickell, S., and Wadhwani, S., 1990, Insider forces and wage determination, The Economic Journal, 100, 401, 496-509.

Nickell, S., and Wadhwani, S., 1989 Insider forces and wage determination, Centre for Labour Economics, London School of Economics, Discussion Paper No. 344, Pohl, G., Anderson, E., Claessens, S., Djankov, P., 1997, Privatisation and restructuring in Central and Eastern Europe, World Bank Technical Paper, No. 368, Finance, Private sector and infrastructure network, Washington.

Rosen, S., 1986, The theory of equalising differences, in Orley, C., and Layard, R., (eds.) The Handbook of Labour Economics, (New York, North Holland).

Sato, Y., 2000, Search theory and the wage curve, Economic Letters, 66, 93-8.

Shapiro, C and Stiglitz, J., 1984, Equilibrium unemployment as a worker discipline device, American Economic Review, 74(3), 433-44.

Van Reenen, J., 1996, The creation and capture of rents: wages and innovation in a panel of UK companies, The Quarterly Journal of Economics, 111, 1, 195-226. 


\section{DAVIDSON INSTITUTE WORKING PAPER SERIES - Most Recent Papers}

The entire Working Paper Series may be downloaded free of charge at: www.wdi.bus.umich.edu

CURRENT AS OF 6/26/03

\begin{tabular}{|c|c|c|}
\hline Publication & Authors & Date \\
\hline $\begin{array}{l}\text { No. 584: Wage Determination: Privatised, New Private and State } \\
\text { Owned Companies, Empirical Evidence from Panel Data }\end{array}$ & $\begin{array}{l}\text { Tomasz Mickiewicz and Kate } \\
\text { Bishop }\end{array}$ & June 2003 \\
\hline No. 583: An Investigation of Firm-Level R\&D Capabilities in East Asia & $\begin{array}{l}\text { Gary H. Jefferson and Zhong } \\
\text { Kaifeng }\end{array}$ & June 2003 \\
\hline $\begin{array}{l}\text { No. 582: R\&D and Technology Transfer: Firm Level Evidence From } \\
\text { Chinese Industry }\end{array}$ & $\begin{array}{l}\text { Albert G.Z. Hu, Gary H. } \\
\text { Jefferson, Guan Xiaojing and } \\
\text { Qian Jinchang }\end{array}$ & June 2003 \\
\hline $\begin{array}{l}\text { No. 581: Credit Market Disequilibrium in Poland: Can We Find } \\
\text { What We Expect? Non-Stationarity and the "Min" } \\
\text { Condition }\end{array}$ & $\begin{array}{l}\text { Christophe Hurlin†and Rafal } \\
\text { Kierzenkowski }\end{array}$ & June 2003 \\
\hline $\begin{array}{l}\text { No. 580: Does it Take a Lula to go to Davos? } \\
\text { A Brief Overview of Brazilian Reforms, 1980-2000 }\end{array}$ & $\begin{array}{l}\text { Nauro F. Campos, Armando } \\
\text { Castellar Pinheiro, Fabio } \\
\text { Giambiagi and Maurício M. } \\
\text { Moreira }\end{array}$ & June 2003 \\
\hline $\begin{array}{l}\text { No. 579: Ceaseless Toil? Health and Labor Supply of the Elderly in } \\
\text { Rural China }\end{array}$ & $\begin{array}{l}\text { Dwayne Benjamin, Loren Brandt } \\
\text { and Jia-Zhueng Fan }\end{array}$ & June 2003 \\
\hline $\begin{array}{l}\text { No. 578: Shadow Economy, Rent-Seeking Activities and the Perils of } \\
\text { Reinforcement of the Rule of Law }\end{array}$ & Ekaterina Vostroknutova & June 2003 \\
\hline $\begin{array}{l}\text { No. 577: No Pain, No Gain: Market Reform, Unemployment, and } \\
\text { Politics in Bulgaria }\end{array}$ & Neven Valev & June 2003 \\
\hline $\begin{array}{l}\text { No. 576: Power Analysis of the Nice Treaty On the Future of European } \\
\text { Integration }\end{array}$ & Yener Kandogan & June 2003 \\
\hline $\begin{array}{l}\text { No. 575: Democracy's Spread: Elections and Sovereign Debt in } \\
\text { Developing Countries }\end{array}$ & $\begin{array}{l}\text { Steven A. Block, Burkhard N. } \\
\text { Schrage, and Paul M. Vaaler }\end{array}$ & June 2003 \\
\hline $\begin{array}{l}\text { No. 574: Reintroducing Intergenerational Equilibrium: Key Concepts } \\
\text { Behind the New Polish Pension System }\end{array}$ & Marek Góra & June 2003 \\
\hline $\begin{array}{l}\text { No. 573: Why Does FDI Go Where It Goes? New Evidence From the } \\
\text { Transition Economies }\end{array}$ & $\begin{array}{l}\text { Yuko Kinoshita and Nauro F. } \\
\text { Campos }\end{array}$ & June 2003 \\
\hline $\begin{array}{l}\text { No. 572: Private Savings in Transition Economies: Are There Terms of } \\
\text { Trade Shocks? }\end{array}$ & Abdur R. Chowdhury & May 2003 \\
\hline $\begin{array}{l}\text { No. 571: On the long-run determinants of real exchange rates for } \\
\text { developing countries: Evidence from Africa, Latin America and Asia }\end{array}$ & Imed Drine and Christophe Rault & May 2003 \\
\hline $\begin{array}{l}\text { No. 570: A re-examination of the Purchasing Power Parity using non- } \\
\text { stationary dynamic panel methods: a comparative approach for } \\
\text { developing and developed countries }\end{array}$ & Imed Drine and Christophe Rault & May 2003 \\
\hline $\begin{array}{l}\text { No. 569: How Important is Ownership in a Market with Level Playing } \\
\text { Field? The Indian Banking Sector Revisited }\end{array}$ & $\begin{array}{l}\text { Sumon Kumar Bhaumik and } \\
\text { Ralitza Dimova }\end{array}$ & May 2003 \\
\hline $\begin{array}{l}\text { No. 568: On Types of Trade, Adjustment of Labor and Welfare Gains } \\
\text { During Asymmetric Liberalizations }\end{array}$ & Yener Kandogan & May 2003 \\
\hline $\begin{array}{l}\text { No. 567: Technological Progress Through Trade Liberalization in } \\
\text { Transition Countries }\end{array}$ & Yener Kandogan & May 2003 \\
\hline $\begin{array}{l}\text { No. 566: Intra-industry Trade of Transition Countries: Trends and } \\
\text { Determinants }\end{array}$ & Yener Kandogan & May 2003 \\
\hline $\begin{array}{l}\text { No. 565: Local Protectionism and Regional Specialization: Evidence } \\
\text { from China's Industries }\end{array}$ & $\begin{array}{l}\text { Chong-En Bai, Yingjuan Du, } \\
\text { Zhigang Tao, Sarah Y. Tong }\end{array}$ & May 2003 \\
\hline No. 564: Corporate Governance and Market Valuation in China & $\begin{array}{l}\text { Chong-En Bai, Qiao Liu, Joe Lu, } \\
\text { Frank M. Song, and Junxi Zhang }\end{array}$ & May 2003 \\
\hline $\begin{array}{l}\text { No. 563: Revenue Sharing and Control Rights in Team Production: } \\
\text { Theories and Evidence From Joint Ventures }\end{array}$ & $\begin{array}{l}\text { Chong-En Bai, Zhigang Tao, and } \\
\text { Changqi Wu }\end{array}$ & May 2003 \\
\hline $\begin{array}{l}\text { No. 562: Financial Dependence, Stock Market Liberalizations and } \\
\text { Growth }\end{array}$ & Nandini Gupta and Kathy Yuan & May 2003 \\
\hline $\begin{array}{l}\text { No. 561: Growth and Regional Inequality in China During the Reform } \\
\text { Era }\end{array}$ & Derek Jones, Cheng Li and Owen & May 2003 \\
\hline
\end{tabular}

